\title{
Protein PML
}

National Cancer Institute

\section{Source}

National Cancer Institute. Protein PML. NCI Thesaurus. Code C34068.

Protein PML (882 aa, $\sim 98 \mathrm{kDa}$ ) is encoded by the human PML gene. This protein plays a role in both transcriptional regulation and PML body formation. 